співробітництва і співтворчості суб'єктів підготовки на основі кооперативних взаємозв'язків, утвердження цінності людської праці й думки; цілісного формування інноваційної спрямованості, рефлексивної поведінки, системного й ситуаційного мислення особистості впродовж тривалого періоду взаємодії та педагогічного супроводу в рамках підготовки. Модель відтворює реальну ринково-педагогічну дійсність професійної підготовки майбутнього вчителя природничих дисциплін, має прогностичний характер та забезпечує особистісний i соціальний результат - якість і конкурентноздатність майбутніх учителів профільної школи на ринку освітніх послуг.

\title{
Література
}

1. Професійно-педагогічна освіта: сучасні концептуальні моделі та тенденції розвитку: [монографія] / авт. кол. О.А. Дубасенюк, О. Є. Антонова, С. С. Вітвицька, Н. Г. Сидорчук, О. М. Спірін, Н. В. Якса та ін.; за заг. ред. проф. О. А. Дубасенюк: [2-е вид., доп. ]. - Житомир : Вид-во ЖДУ ім. І. Франка, 2008. - 380 с.

2. Сидорчук Н. Г. Організація самоосвітньої діяльності майбутніх учителів у процесі вивчення предметів педагогічного циклу : дис. ... канд. пед. наук : 13.00 .04 / Н. Г. Сидорчук. - К., 2002. -218 с.

3. Томашевський В. М. Моделювання систем / В. М. Томашевський. - К. : Видавнича група BHV, 2005. - 352c.

4. Шутюк С. В. Моделирование системы взаимоотношений крупных компаний с регионами : [научная монография] / С. В. Шутюк. - М. : ВИНИТИ РАН, 2006. -336 c.

Стаття надійшла до редакції 27.05.2012 p.

УДК 378.147:373.3

I. В. Онищенко, кандидат філол. наук, дочент, Криворізький педагогічний інститут ДВНЗ «Криворізький національний університет»

\section{ФОРМУВАННЯ ТВОРЧОЇ КОМПЕТЕНТНОСТІ МАЙБУТНЬОГО ВЧИТЕЛЯ ПОЧАТКОВИХ КЛАСІВ У ПРОЦЕСІ ПРОФЕСІЙНОЇ ПІДГОТОВКИ}

Онищенко І. В. Формування творчої компетентності майбутнього вчителя початкових класів у прочесі професійної підготовки.

У статті розглянуто проблему формування творчої компетентності майбутнього вчителя початкових класів, визначено сутність, структуру, умови та шляхи формування творчої компетентності майбутнього вчителя початкової школи у прочесі фахової підготовки.

Ключові слова: компетентність, творча компетентність, творча особистість, творчий учитель, творча активність.

Онищенко И. В. Формирование творческой компетентности будущего учителя начальных классов в прочессе профессиональной подготовки.

В статье рассматривается проблема формирования творческой компетентности будущего учителя начальных классов, определяется сущность, структура, условия и пути формирования творческой компетентности будущего учителя начальной школь в процессе профессиональной подготовки.

Ключевые слова: компетентность, творческая компетентность, творческая личность, творческий учитель, творческая активность. 

the training.

Onishchenko I. The formation of the creative competence of future teachers of primary classes in

The article considers the problem of formation of the creative competence of the future primary school teachers, determines the essence, structure, ways and conditions of formation of the creative competence of future primary school teachers in the process of training.

Key words: competence, the creative competence, creative personality, creative teacher, creative activity.

Постановка проблеми. Сучасна початкова освіта потребує педагогів, які не тільки мають достатній запас професійних знань, умінь, навичок, а й готові успішно реалізувати свій творчий потенціал, володіють творчою індивідуальністю, здатні до педагогічної творчості та інноваційної діяльності. У зв'язку з цим актуалізується проблема формування професійної творчої компетентності майбутніх учителів початкових класів.

Гуманістична спрямованість праці сучасного вчителя початкових класів неможлива без компетентного і творчого здійснення педагогічної діяльності. За цієї умови творчий складник педагогічної праці останнім часом розглядається як найважливіший показник ефективності педагогічних дій. Адже, педагог 3 нерозвиненою творчої компетентністю відчуває серйозні труднощі у професійній діяльності.

Отже, пошук резервів вдосконалення професійної підготовки вчителя початкових класів, і як професіонала, і як творчої особистості, яка володіє професійно-творчої компетентністю, $\epsilon$ актуальною проблемою сучасної початкової освіти.

Аналіз останніх досліджень та публікацій. Аналіз психолого-педагогічної літератури доводить, що сучасною наукою накопичено значний фонд ідей, спираючись на які можна успішно розв'язувати проблему формування творчої компетентності майбутнього вчителя.

Загальнотеоретичні засади формування професійної компетентності розкрито у працях Н. Буринської, В. Байденко, Л. Величко, А. Грабецького, Е. Зеера, І. Зимньої, А. Маркової, Л. Митіної, С. Рачева та інших; специфіка підготовки професійно-педагогічних кадрів для початкової освіти відображені в працях О. Біди, В. Бутенка, Є. Голобородько, Л. Коваль, В. Молчанової, О. Петухової, О. Пєхоти, Т. Тесленко, С. Якименко та інших.

Закономірності й чинники становлення творчої особистості педагога обгрунтовані в працях В. Андрєєва, Д. Богоявленської, В. Загвязинського, І. Зимньої, В. Кан-Каліка, Н. Кузьміної, Н. Кухарєва, М. Лазарєва, Л. Мітіної, М. Поташника, А. Щербакової та інших. Особливості творчої педагогічної діяльності вивчалися такими науковцями, як Є. Бондаревська, В. Загвязинский, В. Кан-Калик, Т. Паніна, Я. Пономарьов, Е. Шиянов, Н. Яковлєва та інші.

Дослідження окремих аспектів професійної творчої компетенції представлені в працях В. Антипець, В. Загвязінського, І. Зязюна, В. Кан-Калика, Н. Кічук, А. Кочубей, Н. Кузьміної, В. Молчанової, Н. Огієнко, Н. Пахтусової, М. Поташника, О. Тутолміна, Р. Шакурова та інших. Однак, аналіз психологопедагогічної та методичної літератури дозволяє констатувати, що у педагогіці відсутні системні дослідження, присвячені формуванню професійної творчої компетенції фахівців у галузі початкової освіти. 
Мета статті полягає у виявленні та обгрунтуванні теоретикометодологічних основ становлення та розвитку професійної творчої компетентності майбутнього вчителя, розкритті умов та шляхів формування творчої компетентності майбутнього вчителя початкових класів.

Виклад основного матеріалу дослідження. Компетентнісний підхід до дослідження проблем педагогічної освіти - це сукупність теоретикометодологічних положень і організаційно педагогічних заходів, спрямованих на створення умов щодо освоєння і трансляції педагогічних цінностей та технологій, що забезпечують творчу самореалізацію особистості вчителя у професійній діяльності. Такий підхід зумовлений тим, що важливим показником якості сучасного вчителя $\epsilon$ не стільки професійні знання, засвоєні вміння навчання і виховання, скільки професійна компетентність, яка забезпечує професійно-особистісний розвиток, творчий підхід до навчання і виховання молодших школярів, здатність надавати компетентну підтримку їх інтелектуального та особистісного розвитку.

У психолого-педагогічній літературі відсутнє однозначне розуміння поняття компетентності (В. Байденко, С. Бондар, В. Кальней, В. Ландшеєр, А. Маркова, Дж. Равен, I. Родигіна, А. Тряпіцина, О.Тутолмін, М. Чошанов, С. Шишов та інші). 3 позиції функціонально-діяльнісного підходу компетентність розглядається як єдність теоретичної та практичної готовності до здійснення педагогічної діяльності, до виконання професійних функцій, при якому основні параметри професійної компетенції задаються функціональною структурою педагогічної діяльності, що охоплює низку теоретичних і практичних умінь: аналітичних, прогностичних, проективних, рефлексивних, організаторських, комунікативних тощо. [4, с. 46].

Професійна компетенція вчителя початкової школи визначається як збірне поняття, що визначає своєрідність особистості вчителя як педагогадидакта, педагога-вихователя та дитячого психолога. В основі професійної компетентності лежить усвідомлення вчителем своїх педагогічних можливостей, особливостей дитячої групи, перспектив іiі розвитку. Таке усвідомлення визначає професійну гнучкість педагога в підборі педагогічних технологій, методик, що дозволяють успішно реалізувати головну мету створити умови для творчого розвитку молодших школярів.

Важливе місце у структурі компетентності посідає творча компетентність, яка передбачає сформованість нестандартного мислення, володіння інноваційними педагогічними технологіями, адаптацію до змін змісту, засобів i методів, умов педагогічної діяльності. У сучасному полікультурному просторі творчу компетентність під час фахової діяльності розглядають як провідний чинник, що впливає на розвиток можливостей майбутнього фахівця й забезпечує його ефективність (В. Антипець, І. Зязюн, В. Молчанова, Н. Пахтусова, М. Поташник, О. Тутолмін, Р. Шакуров та інші).

Творча компетентність - це інтегративна професійно-особистісна характеристика вчителя, що забезпечує йому ефективність діяльності в типових i неординарних ситуаціях шкільного життя, що $\epsilon$ 
системоутворюючим компонентом у структурі професійно-педагогічної компетентності, чинником становлення професіоналізму майбутнього вчителя, продуктивності його педагогічної діяльності, педагогічного спілкування, особистісної самореалізації, умовою компетентної підтримки творчого розвитку учнів [5, с. 289].

Н. Пахтусова зауважує, що сутність професійної творчої компетенції педагога виражається в тому, що, заломлюючись через професійну діяльність, вона виявленняляється у більш високій якості цієї діяльності та більш високому рівні розвитку творчої індивідуальності педагога. Професійна творча компетенція як суб'єктивне явище відрізняється динамічністю, мінливістю за рахунок тих перетворень, які відбуваються в досвіді педагога, розвитку його творчого потенціалу [2, с. 13].

На тому, що розвиток творчої компетентності під час підготовки фахівців є обов’язковою умовою формування їхньої професійної компетентності наголошували такі вчені: Д. Богоявленська, В. Загвязинский, Е. Ілієнков, В. Кан-Калик, Н. Кухарєв, А. Лосєв, А. Матюшкін, В. Молчанова, Т. Паніна, Н. Пахтусова, Я. Пономарьов, Н. Посталюк, Е. Шиянов, Н. Яковлєва та інші.

Творчу компетентність вчителя початкових класів ми розглядаємо як сукупність здібностей, якостей і властивостей педагога, необхідних для успішної професійно-творчої діяльності в умовах початкової школи, творчого виконання ним професійних функцій, забезпечення креативного розвитку молодших школярів, творчого (нестандартного) формулювання i розв’язування педагогічних завдань.

Творча компетентність вимагає від вчителя початкової школи таких професійно значущих якостей особистості, як креативність, педагогічна ерудиція, творча активність, творча фантазія, розвинене уявлення, самостійність суджень, цілеспрямованість, аналітичність, прогностичність, педагогічна умілість, емпатія, рефлексія, проникливість.

На нашу думку, творча компетентність вчителя початкових класів у своїй структурі містить такі компоненти:

1) мотиваційний (готовність до виявлення компетентності), який передбачає: інтерес до творчої діяльності, мотиви професійної творчості, мотиви творчого саморозвитку, мотиви творчих досягнень;

2) когнітивний (знання змісту компетентності), який передбачає: знання про особливості творчої професійної педагогічної діяльності, про роль педагогічної творчості та творчого саморозвитку в педагогічній діяльності;

3) діяльнісний (досвід вияву компетентності у різних ситуаціях), що передбачає гностичні, проектувальні, дослідницькі, організаційні вміння та професійно важливі творчі якості, сукупність яких забезпечує повноцінну реалізацію професійно-творчої діяльності педагога, їі ефективність і продуктивність (творча активність, емпатійність, креативність, рефлективність, самооцінка);

4) емоційно-вольовий (здатність адекватно ситуаціям регулювати виявлення компетентності), який включає: уміння концентрувати власні творчі сили, емоційне ставлення до творчості, сміливість і незалежність у судженнях. 
Практика переконує, що лише творчий учитель, який удосконалює свою педагогічну майстерність залишається цікавим для учнів і може спонукати їх до творчості під час навчального процесу. Отже, для того, щоб процес навчання був більш ефективним, педагогу слід заздалегідь продумати розмаїття педагогічних технологій, а також урахування умов виникнення творчого стану в майбутніх фахівців початкової школи.

Формуванню творчої компетентності майбутнього вчителя початкових класів сприяють такі прийоми і форми колективної роботи:

- конкурси педагогічної майстерності;

- імпровізована театралізація педагогічних мініатюр;

- педагогічні олімпіади;

- студентські наукові конференції;

- розвивальні творчі ігри;

- ділові ігри;

- брейн-ринг, вікторина, КВК;

- робота проблемних груп та наукових гуртків;

- виконання конкурсних робіт;

- виробнича педагогічна практика.

Ефективним засобом формування творчої компетентності майбутнього вчителя початкових класів $€$ творчі завдання типу: завдання-проблеми, завдання-парадокси, завдання на прогнозування, на рецензування, на вибір оптимального рішення, дослідницькі завдання, комунікативно-творчі завдання, задачі на встановлення причинно-наслідкових зв'язків, експериментальні завдання, завдання на моделювання, завдання на розвиток фантазії та уявлення та ін. Ці завдання грунтуються на наявних знаннях студентів з психолого-педагогічних дисциплін, максимально реалізують творчий потенціал студентів, активізують творчі уміння, розвивають дивергентне мислення.

Проблема формування творчої компетентності майбутнього вчителя початкових класів пов'язана зі створенням умов для підвищення рівня його спрямованості на творчу професійну діяльність, готовності творчості. На нашу думку, умовами, що забезпечують ефективність становлення та розвитку творчої компетентності майбутнього вчителя початкової школи є:

- реалізація компетентнісного підходу;

- забезпечення творчої атмосфери на заняттях;

- власний приклад творчого підходу до розв'язання педагогічних завдань;

- оволодіння майбутнім учителем технологіями інноваційної освіти;

- створення ситуації зацікавленості особистості в праці та їі результатах;

- забезпечення можливостей для тренування і практики;

- активізація науково-дослідницької діяльності;

- виховання інтересу до творчої діяльності;

- реалізація особистісно розвивального підходу.

Важливою умовою становлення та розвитку творчої компетентності майбутнього вчителя початкових класів $\epsilon$ забезпечення творчого розвивально-освітнього середовища, що характеризується творчою 
атмосферою співробітництва та співтворчості, створює сприятливі умови для професіоналізації: атмосферу творчого пошуку, можливість для самореалізації, вільного саморозвитку і співпраці.

Висновки. Аналіз особливостей педагогічної діяльності вчителя початкових класів, виявлення іiі творчого характеру та спрямованості на саморозвиток і самовдосконалення педагога дозволив зробити висновок про значимість творчої компетентності в структурі професійної компетентності педагога. Творча компетентність вчителя початкової школи є визначальним чинником його професіоналізму, продуктивності педагогічної діяльності, особистісної самореалізації, умовою компетентної підтримки творчого розвитку молодших школярів. Творча компетентність учителя початкових класів забезпечує ефективність його діяльності в різноманітних ситуаціях педагогічного спілкування в умовах початкової школи, та у своїй структурі поєднує психолого-педагогічні та методичні знання, педагогічну ерудицію, креативність, творчу активність, професійне педагогічне мислення, спеціальні здібності та вміння, творчу готовність.

\section{Література}

1. Загвязинский В. И. Педагогические творчество учителя / В.И. Загвязинский. М. : Педагогика, 1987. - 160 с.

2. Пахтусова Н. А. Формирование профессиональной творческой компетенции будущих педагогов профессионального обучения в условиях вуза: автореф. дис. ... канд. пед. наук : 13.00.08 / Пахтусова Наталья Александровна. - Челябинск, 2011. - 25 с.

3. Сисоєва С. О. Основи педагогічної творчості: [підручник] / Світлана Олександрівна Сисоєва. - К. : Міленіум, 2006. - 346 с.

4. Сластёнин В. А. Педагогика: инновационная деятельность / В. А. Сластёнин, С. Л. Подымова. - М. : Магистр, 1997. - 224 с.

5. Тутолмин А. В. Концепция развития творческой компетентности педагога начального образования в процессе профессионализации / А. В. Тутолмин // Современные наукоемкие технологии. - 2010. - № 7. - С. 289-290.

Стаття надійшла до редакції 30.05.2012 р.

\section{ПІДВИЩЕННЯ ЕСТЕТИЧНОЇ КУЛЬТУРИ СТУДЕНТІВ ПІД ЧАС ВЗАСМОПОВ'ЯЗАНОГО ВИВЧЕННЯ УКРАЇНСЬКОЇ ТА ЗАРУБІЖНОЇ ЛІТЕРАТУРИ \\ (на матеріалі спецкурсу «Актуальні питання української і зарубіжної літератури»)}

Папушина В. А. Підвищення естетичної культури студентів під час взаємопов'язаного вивчення украӥнської та зарубіжної літератури (на матеріалі спецкурсу "Актуальні питання украӥнської і зарубіжної літератури»).

У статті обтрунтовано значення спецкурсу «Актуальні питання української $і$ зарубіжної літератури» для формування естетичної культури студентів, розглянуто форми та методи підвищення естетичної культури студентів на матеріалі даного спецкурсу, зокрема під час вивчення роману I. Нечуя-Левиџького «Хмари» та збірки оповідань I. Тургенєва «Нотатки мисливия». 